\title{
Distant Learning: Open Challenges and Evolution
}

\author{
Fernando Ferri, Alessia D’Andrea*, Patrizia Grifoni, Tiziana Guzzo \\ Institute for Research on Population and Social Policies, Rome, Italy
}

\begin{abstract}
The evolution of Information and Communication Technologies has changed the learning sector by stimulating the development of distant learning based approaches (electronic, mobile, ubiquitous and blended learning). Distant learning consists of delivering lessons remotely without a face-to-face contact between a teacher and the learners. It produces many changes to conventional learning in classroom. The paper discusses the open challenges in distant learning by classifying them in the perspective of actors involved in: teacher, institution and learner. A discussion on the evolution of the different distant learning approaches is also provided in the paper. Technologies, characteristics, advantages and limitations of each approach have been analysed. By considering future perspectives, the analysis of the literature underlines the need (i) to support distant learning with multimodal interaction facilities and (ii) to test the learning opportunities offered by other channels of communication such as digital cable, satellite and web TV although with significant differences in targets involvement (in relation to age, status, etc).
\end{abstract}

Keywords: distant learning; e-learning; mobile learning; ubiquitous learning; blended learning.

\section{Introduction}

In July 2018 over 4.1 billion people were active internet users and 3.3 billion were social media users. India, China and US rank ahead all other countries in terms of internet users (Worldwide digital population, 2018). The widespread diffusion of digital technologies had impacts in many sectors (works, social life, education etc.). This paper analyses how digital technologies influenced the learning context by stimulating the development of distant learning approaches.. Distant learning is a way of providing education without a human contact. The development of Information and Communication Technologies (ICT) has producing many changes to conventional learning in classroom. The change started with the spread of Web 1.0 technologies that allow students to consume static web pages and read web pages written by others. With the development of Web 2.0 learners had the possibility to create and share contents. The Web 3.0 
represents an evolution that allows a faster and more intuitive web experience. The next generation of electronic learning (e-learning) is the ubiquitous learning that enables accessing resources through mobile devices. However, it is more and more common the opinion that distance learning combined with face-to-face practices can improve the learning activities. Indeed, current trend is represented by blended learning, a hybrid approach that combines distant and face-to-face learning. Starting from these considerations, the paper aims to analyse the evolution of distant learning. Different approaches (electronic, mobile, ubiquitous and blended learning) are discussed in the paper underlining their technologies, characteristics, advantages and limitations.

The paper is structured as follows. Section 2 provides an introduction on open challenges in distant learning. In Section 3, an analysis of the evolution of learning approaches: electronic, ubiquitous, and blended learning is provided. Finally, section 4 concludes the paper.

\section{Open challenges in distant learning}

Technological advances have renewed learning practices; they bring many challenges within the different kinds of distant learning approaches: electronic, mobile, ubiquitous and blended learning. The NMC Horizon Report (2013) identifies key emerging challenges underlining important constraints such as: professional development; resistance to changes; failures of personalized learning and formative assessments. Other major challenges are represented by the building of strong multi-sector partnerships (Shuler et al., 2013); the lack of adequate infrastructure (Cardullo et al., 2016); the identification of the best use of technologies and their matching with learners and outcomes in the definition of learning activities (Agarwal, 2011).

We classified these challenges in the perspective of actors involved in: teacher, institutional and learner (see Table 1).

Table 1. Open challenges in distant learning (own elaboration based on literature inputs)

\begin{tabular}{|c|c|c|}
\hline LEVEL & CHALLENGES & ISSUES \\
\hline \multirow{4}{*}{ TEACHER } & $\begin{array}{c}\text { PROFESSIONAL } \\
\text { DEVELOPMENT }\end{array}$ & $\begin{array}{c}\text { Lack of adequate professional } \\
\text { development }\end{array}$ \\
\cline { 2 - 3 } & $\begin{array}{c}\text { CONTRASTING THE } \\
\text { RESISTANCE TO CHANGE }\end{array}$ & $\begin{array}{c}\text { Resistance to technology use and } \\
\text { preference for traditional } \\
\text { learning }\end{array}$ \\
\hline \multirow{3}{*}{ INSTITUTIONAL } & $\begin{array}{c}\text { OVERCOMING FAILURES } \\
\text { FOR PERSONALIZED } \\
\text { LEARNING }\end{array}$ & $\begin{array}{c}\text { Gap between the vision of } \\
\text { delivering personalized and } \\
\text { available resources }\end{array}$ \\
\cline { 2 - 3 } & $\begin{array}{c}\text { DELIVERING EFFECTIVE } \\
\text { FORMATIVE } \\
\text { ASSESSMENTS }\end{array}$ & $\begin{array}{c}\text { Difficulties in changing curricula } \\
\text { and skill demands }\end{array}$ \\
\cline { 2 - 3 } & BUILDING STRONG \\
MULTI-SECTOR \\
& PARTNERSHIPS & Small-scale and localized pilots \\
& & \\
\hline
\end{tabular}




\begin{tabular}{|c|c|c|}
\hline & $\begin{array}{l}\text { LACK OF ADEQUATE } \\
\text { INFRASTRUCTURE }\end{array}$ & Access learning activities with \\
\hline LEARNER & $\begin{array}{l}\text { IDENTIFYING THE BEST } \\
\text { USE OF TECHNOLOGIES } \\
\text { AND MATCHING THEM } \\
\text { WITH LEARNERS AND } \\
\text { OUTCOMES IN THE } \\
\text { DESIGN OF LEARNING } \\
\text { ACTIVITIES }\end{array}$ & $\begin{array}{l}\text { How to stimulate learning } \\
\text { processes } \\
\text { Which learning materials are } \\
\text { most effective } \\
\text { Which learning activities are } \\
\text { appropriate }\end{array}$ \\
\hline
\end{tabular}

Teachers need to undertake certain tasks such as coaching, assessing and providing subject matter expertise. All these activities may represent a problem for teachers that continue to have a poor experience with ICT. According to Johnson et al. (2014), the poor ICT literacy skills by teachers are attributed to a low administrative support and a lack of dedicated funding. A key resistance challenge is also represented by the "comfort with the status quo" due to the teacher's resistance to changes introduced by the ICT novelties.

On considering institutional level barriers, the technology inaccessibility, the lack of adequate support (technical and institutional), and the lack of funding represent obstacles for personalized learning environments and formative assessments. At this level, the building of strong multi-sector partnerships is very important to foster widespread uptake: currently distant learning presents a small-scale, with results based on localized pilots. In order to go beyond the pilot stage, policy-makers should play a key role in promoting multi-sector partnerships, which are needed to connect disparate efforts, drive innovation and ensure the expansion of successful distant learning projects. Cardullo et al.; (2016) underlined that all learners and educators need accessing comprehensive infrastructure for learning everywhere and every time.

Finally, at learner level, a big challenge is to match the use of devices with learning activities, considering when and how to use them (Agarwal, 2011). Some key elements to plan ubiquitous learning are: learners, outcomes and environment, and the dynamic interaction between these elements.

An important challenge also concerns the personalisation of distant learning activities in terms of time, place, or frequency in accessing the learning materials. For designing learning activities, it is necessary to consider some issues such as: needs and motivations of learners, their experiences, their ICT competences and, learning preferences. From a pedagogical perspective, it is necessary to consider curriculum aspects such as distant learning approaches, evaluation and assessment criteria like feedback, achievement of learning objectives. The challenges that still persist concern the users' knowledge, needs, background, preferences, etc. 


\section{Distant learning evolution}

The next sub-sections describe the evolution of the different distant learning approaches by discussing technologies, characteristics, advantages and limitations of each of them. Distant learning has a very long tradition and it consists of delivering lessons remotely without a face-to-face contact between a teacher and the students. In the past, this kind of learning organised correspondence courses or courses using television and telephone. Yet, the ICT evolution has changed the learning sector by stimulating the development of the different approaches described below: electronic, mobile, ubiquitous and blended learning

\subsection{Electronic learning}

E-learning represents the primary form of distant education, which takes advantage from the ICT (Sangrà et al., 2012). The first generation of e-learning was grown with the emergence of Web 1.0; it is recognised as "read-only web". The advantages of this first generation of e-learning were mainly in terms of a greater learner autonomy thanks to the use of authentic materials (opened for learners) readily available for many languages and users within new learning scenarios.

Since the early years of the twenty-first century, the diffusion of Web 2.0 technologies (blogs, wikis, social networks, virtual communities and other similar tools) allowed users not only to make use of content created by others, but also to generate and publish their own. The advent of the e-learning 2.0 stimulated the diffusion of the collaborative learning approach enhancing a real interaction and communication sometimes involving different sectors (Caschera et al. 2010, Ferri et al., 2008, Ferri et al., 2012; D'Andrea et al., 2012; D'Andrea et al., 2010, D'Andrea et al., 2011, Guzzo at al., 2013). An \& Williams in their paper published in 2010, underlined that the use of e-learning 2.0 presented some important disadvantages such as: the difficulties in using the collaborative approaches provided by the Web 2.0 technologies (in Table 2 this difficulty is cited as "uneasiness with openness"), technical problems and time. On considering technical problems some Web 2.0 technologies at the beginning presented some problems in working well with the existing learning management systems. Learners also underlined that Web 2.0 technologies require to spend time for acquiring knowledge related to the used technology instead of concentrating them self on the contents.

A further generation of e-learning has been developed and supported by the Web 3.0 that focuses on the contents and their semantics (e-learning 3.0). Its advantages are: (i) the learning materials are easily connected with and achieved through semantic queries (ii) the ontologies allow learners customising their searches for learning material according to their needs (iii) the use of intelligent agents for filtering and organising information allows a more accurate and faster request's results (iii) the semantic queries that lead accessing to the needed content in an easy way (iv) the semantic annotation of content allows adapting the content to the user's needs (v) users have the possibility to use the Web as an integrated platform for the learning activities (vi) the quick and active content delivery stimulates a dynamic learning context (vii) contents 
are more cooperative as the Web is decentralized (Sheeba et al., 2012). However the e-learning 3.0 will also present some disadvantages that include vagueness, vastness, inconsistency, uncertainty and deceit. (Rubens et al., 2014). According to Alkhateeb et al. (2010) the most important issues are represented by the privacy and the loss of control, as "new services on the Internet can be swiftly integrated into existing applications such as integrating Wiki with Web 3.0. The primary risk comes from the fact that students and lecturers are not entirely realized that their universities do not control these web services".

In Table 2 the technologies, characteristics, advantages and limitation of elearning are summarised.

Table 2. Technologies, characteristics, advantages and limitations of e-learning 1.0, 2.0 and 3.0

\begin{tabular}{|c|c|c|c|c|}
\hline & TECHNOLOGIES & CHARACTERISTICS & ADVANTAGES & LIMITATIONS \\
\hline \multirow{2}{*}{$\begin{array}{l}\text { E- } \\
\text { LEARNING }\end{array}$} & $\begin{array}{l}\text { Web } 1.0 \text { (Read-only } \\
\text { web) }\end{array}$ & $\begin{array}{l}\text { Traditional copyrights } \\
\text { materials. } \\
\text { Traditional learning } \\
\text { approaches supported } \\
\text { by test and/or group } \\
\text { work activities within } \\
\text { classroom. } \\
\text { Passive absorptive of } \\
\text { learner behavior }\end{array}$ & $\begin{array}{l}\text { Learner } \\
\text { autonomy } \\
\text { Authentic } \\
\text { materials within } \\
\text { new learning } \\
\text { enviroments } \\
\text { Multiliteracies }\end{array}$ & Low interactivity \\
\hline & $\begin{array}{lr}\text { Web } \quad 2.0 & \text { (Read- } \\
\text { write } & \text { web) }\end{array}$ & $\begin{array}{l}\begin{array}{l}\text { Copyright and free } \\
\text { open learning } \\
\text { resources for learners. }\end{array} \\
\text { Increasing } \\
\text { collaboration/interacti } \\
\text { on in learning activities } \\
\text { through Social Media } \\
\text { Emerging sense of } \\
\text { ownership of the } \\
\text { learning process. }\end{array}$ & $\begin{array}{l}\text { Collaboration, } \\
\text { interaction and } \\
\text { communication } \\
\text { Creation of } \\
\text { knowledge } \\
\text { Flexibility and } \\
\text { ease of use } \\
\text { Technological } \\
\text { skills }\end{array}$ & $\begin{array}{l}\text { Uneasiness with } \\
\text { openness } \\
\text { Technical } \\
\text { problems } \\
\text { Time }\end{array}$ \\
\hline
\end{tabular}




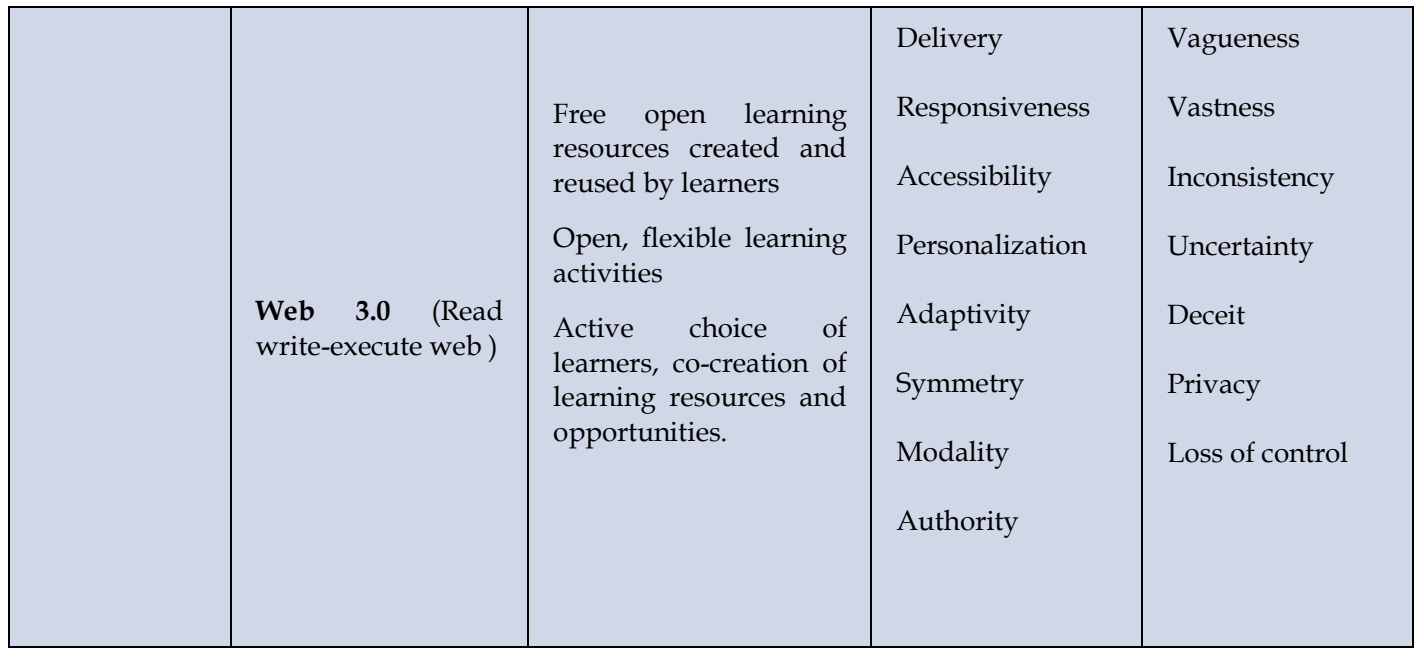

\subsection{Mobile and ubiquitous learning}

The diffusion of mobile devices brought important changes in the acquisition and transmission of knowledge within learning environments. Mobile learning (m-learning) is not only an extension of e-learning; it is "often highly dynamic, targeted to the user's current context and learning needs in respect to e-learning" (Parsons, 2006). This approach gives a new dimension to learning activities (D'Andrea et al., 2009). Mobile devices provide a new way of conversation that is collaborative and integrated. However m-learning has important limitations due to: the screen size of mobile devices (very small), the difficulty of Internet navigation, keyboard limitations, battery power limitations, and the size of the text that makes difficult reading for long time periods. Table 3 summarises technologies, characteristics, advantages and limitation of m-learning.

Table 3. Technologies, characteristics, advantages and limitations of m-learning

\begin{tabular}{|c|c|c|c|c|}
\hline & TECHNOLOGIES & CHARACTERISTICS & ADVANTAGES & LIMITATIONS \\
\hline $\begin{array}{l}\text { M- } \\
\text { LEARNING }\end{array}$ & $\begin{array}{l}\begin{array}{l}\text { Mobile smart } \\
\text { phones }\end{array} \\
\text { Handheld } \\
\text { computers, } \\
\text { Digital assistants }\end{array}$ & $\begin{array}{l}\text { Ubiquitous } \\
\text { Portability of mobile } \\
\text { devices } \\
\text { Blended } \\
\text { Private } \\
\text { Interactive } \\
\text { Collaborative } \\
\text { Instant information }\end{array}$ & $\begin{array}{l}\text { Connectivity } \\
\text { Interactivity } \\
\text { Individuality } \\
\text { Context } \\
\text { sensitivity } \\
\text { Portability }\end{array}$ & $\begin{array}{l}\text { Small screen size } \\
\text { Keyboard } \\
\text { limitations } \\
\begin{array}{l}\text { Difficulty of } \\
\text { Internet } \\
\text { navigation }\end{array} \\
\text { Limited battery } \\
\text { power }\end{array}$ \\
\hline
\end{tabular}

The limitations of m-learning are overcome by the ubiquitous learning ( $u$ learning) that incorporates adaptivity and personalization to mobile learning 
systems (Boyinbode \& Akintola, 2008). Among advantages of the u-learning, Kolomvatsos (2007) indicates an improved efficiency in teaching and learning. Indeed, learners become more and more pro-active as they can build their knowledge through collaboration with their classmates directly using their devices. Furthermore using personal devices, learners do not have problems in understanding functioning of the different tools and can focus on learning. Yahya et al., (2010) summarised some positive characteristics of the u-learning underling that learners can:

- never lose their work unless they purposely remove it; information is continually recorded;

- access their data, documents, etc. whenever they need on the basis of their requests;

- immediately obtain information, therefore they can quickly solve their problems;

- interact both with devices and with teachers, experts and peers efficiently and effectively through different devices sometimes in synchronous and sometimes in asynchronous way. The level of interactivity achieved is very high;

- receive adequate information because the environment can adapt to their real situation.

The cost of ubiquitous devices could represent a limitation on the side of the novelty of the teaching style. Another issue is teachers and learners expertise with ubiquitous technologies and with the new kind of lessons. They could use ubiquitous technologies in an inappropriate way. In Table 4 the technologies, characteristics, advantages and limitation of u-learning are summarised.

Table 4. Technologies, characteristics, advantages and limitations of u-learning

\begin{tabular}{|c|c|c|c|c|}
\hline & TECHNOLOGIES & CHARACTERISTICS & ADVANTAGES & $\begin{array}{l}\text { LIMITATION } \\
\mathrm{S}\end{array}$ \\
\hline $\begin{array}{l}\text { U- } \\
\text { LEARNING }\end{array}$ & $\begin{array}{l}\text { Smart phones } \\
\text { Tablet } \\
\text { Glasses } \\
\text { Sensors RFID } \\
\text { PDAs } \\
\text { Bluetooth } 4.0 \\
\text { Computers } \\
\text { embedded in objects }\end{array}$ & $\begin{array}{l}\text { Permanency } \\
\text { Accessibility } \\
\text { Immediacy } \\
\text { Interactivity } \\
\text { Context-awareness }\end{array}$ & $\begin{array}{l}\text { Teaching/learnin } \\
\text { g efficiency } \\
\text { Access to } \\
\text { technology } \\
\text { Ease of use } \\
\text { Productivity } \\
\text { Portability }\end{array}$ & $\begin{array}{l}\text { Cost } \\
\text { Teacher's } \\
\text { expertise } \\
\text { Inappropriate } \\
\text { use of } \\
\text { technology } \\
\begin{array}{l}\text { Equipment } \\
\text { damage }\end{array}\end{array}$ \\
\hline
\end{tabular}

\subsection{Blended learning}

Learning approaches are also evolving towards blended learning (b-learning) approaches, which combine on-line learning with traditional learning. Graham (2006, defined blended learning as "systems combine face-to-face instruction 
with computer-mediated instruction" (p. 5), The convergence of the two learning approaches allows: (i) focusing on students expectations and needs, (ii) enhancing the student engagement and accessibility, (iii) promoting students' retention, (iv) developing and using innovative technological learning approaches (Fulkerth, 2009). Graham (2005) identified the following advantages of b-learning:

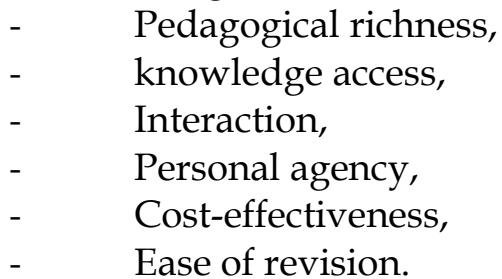

The authors found that b-learning is able to improve pedagogy and increase access and learning flexibility. Guzzo et al. (2012) found that b-learning allows interaction improving collaboration and social relationships among learners and between learners and the moderator. B-learning programmes also allow learners to take part to online learning activities, reducing the time and costs of face-toface lectures.

Table 5 summarises the technologies, characteristics, advantages and limitation of blended learning.

Table 5. Technologies, characteristics, advantages and limitations of blended learning

\begin{tabular}{|l|l|l|l|l|}
\hline & TECHNOLOGIES & CHARACTERISTICS & ADVANTAGES & LIMITATIONS \\
\hline B- & $\begin{array}{l}\text { Computer-Based } \\
\text { Training (via a CD- } \\
\text { ROM, Web-Based } \\
\text { Training }\end{array}$ & $\begin{array}{l}\text { Convergence of two } \\
\text { learning } \\
\text { environments: and } \\
\text { synchronous and } \\
\text { human interaction } \\
\text { and asynchronous } \\
\text { and text based }\end{array}$ & $\begin{array}{l}\text { Pedagogical } \\
\text { richness } \\
\text { Access } \\
\text { knowledge to } \\
\text { Social interaction } \\
\text { Personal agency } \\
\text { Cost- } \\
\text { effectiveness } \\
\text { computer skill. } \\
\text { access }\end{array}$ & internet \\
\hline
\end{tabular}

\section{Conclusion, future perspectives and suggestions}

The paper sketches the evolution of different distant learning approaches: electronic, mobile, ubiquitous and blended learning. E-learning represents the primary form of distant education which has always taken advantage of the latest ICT. M-learning, which extends E-learning, represents a valid support for learning experiences, integrating them with the dynamism of the world beyond the classroom supporting also life-long and informal learning thanks to the 
advantages of mobile devices (mobile phones, handheld computers, personal digital assistants and so on). M-learning allows learners to complete activities in a variety of settings and in different situations (cultural, environmental, spatial, etc.). Mobility and the different situation stimulate the need of adaptivity and personalization of learning environment producing the arising of u-Learning, The use ubiquitous technologies is improving the opportunities of people to access knowledge, changing the roles of the different actors involved in the learning process. M-learning already enabled each person to use and produce knowledge to be shared (peer2peer knowledge Sharing). The u-learning is amplifying this tendency. Promoting peer2peer knowledge sharing through the participation and involvement of the different actors of learning process represents an important challenge for the educational sector. This challenge requires the involvement of strong learning communities both at local and international level and the use of innovative techno-logical approaches for enhancing student experience. It is in this perspective that is emerging the tendency to adopt hybrid approaches (blended learning). Blended-learning is the approach that conciliates the pros and cons of e-learning and face-to-face learning. This approach is also deeply compatible with all the different technologies which are more and more daily used (such as mobile/smart phones). This aspect is particularly relevant for overcoming the difficulties and barriers related to the usability of the emerging technologies. The technology evolution allows sharing contents in different formats (text, voice, video, images etc.) Most of the existing platforms allow sharing multimedia contents. Some of the most popular platforms are the following: Moodle, Learning Heroes: Unconscious Bias Titleist: Vokey Design SM6 Education Course, Nuggethead: PwP Story.

On considering future perspectives, there is the need to support distant learning with multimodal interaction facilities. Multimodality enables the creation of multiple representations of knowledge, which offers the capability of supporting each other. In this way it is possible to inject and deliver learning content in a variety of ways. The situated learner in this sense can also be seen as a person with restricted interaction facilities that should be supported with the complementary information channels currently available. A prototype focused on cognitive and learning processes is provided by Caschera et al. (2011). The platform is based on game-based learning; that allows making the interaction participative with respect to standard graphical interfaces.

Another important prospective is represented by the need to test learning opportunities offered by other channels of communication such as digital cable, satellite and web TV although with significant differences in targets involvement (in relation to age, status, etc). The experiences of testing/implementing multichannel solutions will also show some areas of interest for the design and formative evaluation such as the link between the channel and type of learning (professional, managerial, etc.), the target (age, cycle life, etc.) and the purpose (renovation, upgrading, professional development). 


\section{References}

Agarwal, S. (2011). Some challenges in designing and implementing learning material for ubiquitous e-learning environment. Journal of Global Research in Computer Science, 2(2), 29-32.

Alkhateeb, F., AlMaghayreh, E., Aljawarneh, S., Muhsin, Z., \& Nsour, A. (2010). Elearning tools and technologies in education: A perspective. In E. Murray (Ed.), The 2010 MIT LINC Conference Proceedings. Massachusetts, USA: MIT

An, Y. J., \& Williams, K. (2010). Teaching with Web 2.0 technologies: Benefits, barriers and lessons learned. International Journal of Instructional Technology and Distance Learning, 7(3), 41-48.

Boyinbode, O.K. \& Akintola, K.G. (2008). A Sensor-Based Framework for Ubiquitous Learning in Nigeria. IJCSNS International Journal of Computer Science and Network Security, 8(11), 401-405.

Cardullo, V. M., Zygouris-Coe, V. V. I., \& Wilson, N. S. (2016). The benefits and challenges of mobile and ubiquitous technology in education. In HumanComputer Interaction: Concepts, Methodologies, Tools, and Applications (pp. 18771899). IGI Global.

Caschera, M. C., D’Andrea, A., D’Ulizia, A., Ferri, F., Grifoni, P., Guzzo, T. (2011). Toward New Communication Paradigms to enhance Cognitive and Learning Processes. Proceeding of the MONET 2011: Sixth International Workshop on MObile and NEtworking Technologies for social applications - Hersonissos, Crete, Greece, 1621 October, 2011, 562-570, Springer-Verlag Lecture Notes in Computer Science.

Caschera, M. C., D'Andrea, A., Ferri, F., Grifoni, P. (2010). Knowledge access and interaction evolution in virtual learning communities. Technologies and Practices for Constructing Knowledge in Online Environments: Advancements in Learning, 113132, IGI Publishing.

D'Andrea, A., Ferri, F., Fortunati De Luca, L., Guzzo, T. (2009). Mobile devices to support advanced forms of e-Learning. Multimodal Human Computer Interaction and Pervasive Services, 389-407, IGI Publishing.

D'Andrea, A., Ferri, F., Grifoni, P. (2011). A Business Model Framework for Second Life. E-Novation for Competitive Advantage in Collaborative Globalization: Technologies for Emerging E-Business Strategie, 34-47. IGI Publishing.

D'Andrea, A., Ferri, F., Grifoni, P. (2012). SNeM2S: a Social Network Model for Marketing Strategies. International journal of e-business development, 2(3), 103-110, World Academic Publishing Co, Limited, Hong Kong (Cina).

D'Andrea, A., Ferri, F., Grifoni, P., Guzzo, T. (2010). Multimodal social networking for healthcare professionals. Proceedings of the Fourth International Workshop on management and interaction with multimodal information content (MIMIC'10) Bilboa (ES), 30 August - 3 September 2010, pp. 147-153. IEEE Computer Society Publishing.

Ferri, F., D'Andrea, A., Grifoni, P. (2012). IBF: An Integrated Business Framework for Virtual Communities. Journal of electronic commerce in organizations, 10(4), 1-13, IGI Global.

Ferri, F., Grifoni, P., \& Guzzo, T. (2008). Social Aspects of Mobile Technologies on Web Tourism Trend. Handbook of research on mobile business: technical, methodological and social perspectives, 293-303. IGI Publishing.

Fulkerth, R. (2009). A Case Study from Golden Gate University: Using Course Objectives to Facilitate Blended Learning in Shortened Courses. Journal of Asynchronous Learning Networks, 13(1), 43-54. 
Graham, C. R. (2006). Blended Learning Systems: Definition, Current Trends, and Future Directions. In Bonk, C. J. E Graham, C. R. (Eds.), The Handbook of Blended Learning: Global Perspectives, Local Designs, 3-21). San Francisco, California: Pfeiffer.

Graham, C. R., Allen, S., \& Ure, D. (2005). Benefits and challenges of blended learning environments. In Encyclopedia of Information Science and Technology, First Edition, 253-259. IGI Global.

Guzzo, T., Ferri, F., \& Grifoni, P. (2013). Social Network's Effects on Italian Teenager's Life. Journal of Next Generation Information Technology, 4(3), 54.

Guzzo, T., Grifoni, P., \& Ferri, F. (2012). Social Aspects and Web 2.0 Challenges in Blended Learning. Blended Learning Environments for Adults: Evaluations and Frameworks, 35-49. IGI Global

Johnson, L., Adams Becker, S., Estrada, V. \& Freeman, A. (2014). NMC Horizon Report: 2014 K-12 Edition. Austin, Texas: The New Media Consortium. Retrieved August 28, 2018 from https://www.learntechlib.org/p/147472/.

Kolomvatsos, K. (2007). Ubiquitous Computing Applications in Education. In Ubiquitous and Pervasive Knowledge and Learning Management: Semantics, Social Networking and New Media to Their Full Potential (pp. 94-117). IGI Global.

NMC Horizon Report (2013). Retrieved from http:/ / redarchive.nmc.org/publications/2013-horizon-report-k12)

Parsons, D., \& Ryu, H. (2006). A Framework for Assessing the Quality of Mobile Learning. In Proceedings of the 11th International Conference for Process Improvement, Research and Education (INSPIRE), Southampton Solent University, UK.

Rubens, N., Kaplan, D., \& Okamoto, T. (2014). E-Learning 3.0: anyone, anywhere, anytime, and AI. In New Horizons in Web Based Learning, 171-180.Springer Berlin Heidelberg.

Sangrà, A., Vlachopoulos, D., \& Cabrera, N. (2012). Building an inclusive definition of elearning: An approach to the conceptual framework. The International Review of Research in Open and Distributed Learning, 13(2), 145-159.

Sheeba, T., Begum, S. \& Bernard, M. (2012). Semantic Web to E-Learning Content. International Journal of Advanced Research in Computer Science and Software Engineering, 2 (10), 58-66.

Shuler, C., Winters, N., \& West, M. (2013). The future of mobile learning: Implications for policy makers and planners. United Nations Educational, Scientific and Cultural Organization (UNESCO), 7-35.

Worldwide digital population (2018). Retrieved from ( https://www.statista.com/statistics/617136/digital-population-worldwide/).

Yahya, S., Ahmad, E. A., \& Jalil, K. A. (2010). The definition and characteristics of ubiquitous learning: A discussion. International Journal of Education and Development using Information and Communication Technology, 6(1), 1. 